\title{
EVALUATION OF HOT-MIX ASPHALT CONTAINING PORTLAND CEMENT TREATED BLAST FURNACE SLAG
}

\author{
H. A. RONDÓN-QUINTANA ${ }^{1}$, J. C. RUGE-CARDENAS ${ }^{2}$, \\ J. G. BASTIDAS-MARTÍNEZ ${ }^{3}$
}

\begin{abstract}
Iron production's waste materials include significant quantities of blast furnace slag (BFS) which could potentially be used as a substitute for natural aggregates in hot mix asphalt (HMA) used in highway projects. Although many of properties of slag are interesting, its porosity and absorption rate would lead to greater consumption of asphalt. For this study, a Portland cement (PC) paste was used to reduce the porosity of a BFS. This PC treated BFS (called BFS-C) was then used in an HMA to replace the coarse fraction of a natural aggregate. Marshall, Indirect Tensile Strength (ITS), resilient modulus and Cantabro tests were then carried out on different HMA mixtures that included BFS-C. Using BFS-C, HMA's resistance under monotonic loading, stiffness under cyclic loading, and resistance to moisture damage increased remarkably. In addition, the Cantabro abrasion resistance of BFS-C improved was better than that of the HMA mixture produced with untreated BFS.
\end{abstract}

Keywords: Blast furnace slag, hot mix asphalt, Portland cement, resistance under monotonic and cyclic loading, resistance to moisture damage, Cantabro

\footnotetext{
${ }^{1}$ Prof., M. Sc., PhD., Eng., Universidad Distrital Francisco José de Caldas, Faculty of Environment and Natural Resources, Avenida Circunvalar sede Vivero UD, Bogotá DC 110131, Colombia, https://orcid.org/0000-0003-29469411, e-mail: harondonq@udistrital.edu.co

${ }^{2}$ Prof., M. Sc., PhD., Eng., Universidad Militar Nueva Granada, Faculty of Engineering, Carrera 11 \#101 80, Bogotá DC, Colombia, https://orcid.org/0000-0002-9100-6058, e-mail: juan.ruge@unimilitar.edu.co

${ }^{3}$ PhD., Eng., Universidad Piloto de Colombia, Faculty of Engineering, Carrera 9 No. 45A - 44, Bogotá DC, Colombia, https://orcid.org/0000-0002-6818-0322,e-mail: juan-bastidas@unipiloto.edu.co
} 


\section{INTRODUCTION}

\subsection{PROBLEM STATEMENT AND OBJECTIVE}

Large quantities of blast furnace slags (BFS) are generated as waste in the production of iron. This material can be used as aggregate in highway construction projects in order to decrease both exploitation of natural aggregates and the space occupied by BFS in landfills. Slags are highly heterogeneous natural materials with interesting and complex characteristics and properties [1]. Their chemical compositions are similar to those of clinker and cement and include pozzolanic compounds, low specific gravity aggregates, particles with rough surface textures and angularity. They adhere well with asphalt [2], but their inter-granular porosity is a very important disadvantage in hot mix asphalts (HMA) because it results in increased absorption and consumption of asphalt [26]. Potentially, one way to deal with this problem would be to fill in the pores with a material that reacts well with the asphalt.

This study used a Portland cement (PC) paste to partially fill the pores of a BFS for later use as a replacement for the coarse natural aggregate used in the production of HMA-19 [7]. An experimental program was designed to evaluate the resistance of the resulting HMAs under monotonic and cyclic loading as well as their resistance to abrasion and moisture damage. According to [8], the experimentation using PC coated aggregates to produce asphalt mixtures began in 1977, however, the authors have found no references to the use of PC in the same manner it is in this study. To this extent, we are presenting an innovative process.

\subsection{PC IN ASPHALT MIXTURES}

$\mathrm{PC}$ is used in asphalt mixtures as filler due to its anti-stripping characteristics [9-11]. It tends to increase the asphalt's mastic stiffness [12] and resistance to rutting [13] while simultaneously mitigating oxidation chemical activity [14] and moisture damage [15-16]. It has also been used as an asphalt modifier, for example, [17] used Superpave testing methods to study the effect of PC additive on several rheological properties of asphalt. They used six PC-to-asphalt (PC/A) ratios and concluded that increasing the PC/A ratio increases the stiffness of asphalts, improves its resistance to rutting at all temperatures, and improves the Superpave high performance grade (PG) temperature. 
PC can also improve the mechanical performance of cold asphalt mixtures [18]. Niazi and Jalili [19] studied cold in-place recycled mixtures with asphalt emulsion that had powdered PC as an additive. They concluded that Marshall stability, the resilient modulus, tensile strength, resistance to moisture damage, and resistance to permanent deformation all increased as the amount of PC additive increased. A similar conclusion was obtained by [20], who incorporated PC as filler in an asphalt concrete. Oruc et al. [21] have recommended the use of emulsified asphalt mixtures as structural layers when $0-6 \%$ of $\mathrm{PC}$ is added as a filler.

PC is also used in the production of cement asphalt mortars (CAM). According to [22-23], CAMs are used to create cushion layers that dissipate mechanical energy and noises generated by highspeed trains. PC increases CAM stiffness as the asphalt to cement $(\mathrm{A} / \mathrm{C})$ ratio decreases. However, the addition of cement can also reduce the temperature sensitivity of CAM [24].

In addition, $\mathrm{PC}$ has been used to reduce the curing period of asphalt emulsion-treated bases since $\mathrm{PC}$ particles consume part of the water present in the asphalt emulsion [25].

\subsection{BFS IN ASPHALT MIXTURES}

BFS produces aggregates with rough surface textures, angular particles, high porosity and good adhesion which are compatible with bituminous binders but which require larger than normal amounts of asphalt $[6,26]$. BFS has particles with lower unit weights and specific gravities than those of natural aggregates [2,5], and asphalt mixtures with BFS show good resistance to stripping and high stability [3]. BFS particles generally show low resistance in Los Angeles abrasion tests, and its field performance has been satisfactory [6]. Ali and Fiaz [27] studied the effects of fly ash and BFS as partial replacements of fine aggregates. Based on Marshall stability and flow at high temperatures, they concluded that both materials can be used as partial replacements for aggregates in asphalt concrete pavements. An experimental program designed by [3] to evaluate the effects of substituting BFS for natural fine particles in an HMA found that, in conjunction with asphalt, the fine BFS tends to generate a material with improved properties of resistance under monotonic loading (higher indirect tensile resistance) and dynamic loading (higher resilient modulus and resistance to permanent deformation and fatigue). Rondón et al. [2] replaced the coarse fraction of a limestone aggregate with a Brazilian BFS measured alternately in terms of mass and volume. When the volume was replaced, all mechanical properties evaluated (Marshall stability, stability/flow 
ratio, indirect tensile strength, resilient modulus, permanent deformation and fatigue resistance, moisture damage resistance, and abrasion resistance in Cantabro test) were enhanced. However, when the mass was replaced, the adhesive properties of the asphalt-aggregate system worsened. On the basis of a study of a warm mix asphalt (WMA), [28] concluded that BFS can be used as a partial substitute for the coarse fraction of aggregates in WMA. When $21 \%$ of the coarse aggregates was replaced with BFS, the mixture's stiffness, resistance to moisture damage, and resistance to abrasion all increased beyond the levels achieved with the control asphalt mixture. Du [29] used a ground granulated blast-furnace slag (GGBS) activated by hydrated lime (HL) to replace the limestone filler of an asphalt emulsion mixture (AEM). He found that AEM with GGBS and HL can be used for pavement base course mainly because the HL and GGBS improve interface bond between asphalt and aggregates and enhance the stiffness modulus of the asphalt binder.

\section{MATERIALS AND METHODS}

\subsection{Characterization OF MATERials}

BFS produced by Acerías Paz del Río in Boyacá, Colombia that was slowly cooled in outdoor air (ACBFS) was used in this study (Fig. 1). Approximately 65\% of the particles in this BFS have shiny black surfaces with hard and rigid appearances. The rest have light green surfaces and are lightweight and easy to abrade with the hands. Some of these float in water. Visually, the BFS particles are more porous than the natural aggregate (NGA) used (Fig. 2). A powdered form of type I PC with a specific gravity of 3.1 was used.

a)

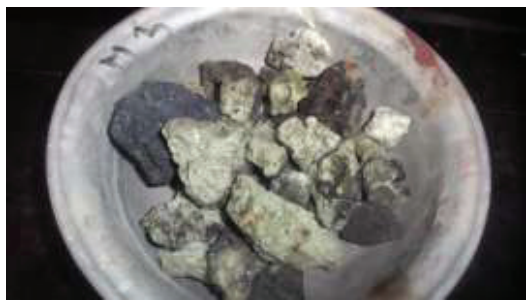

b)

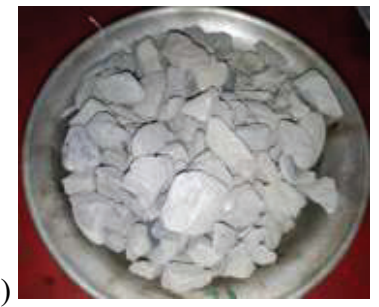

Fig. 1. a) BFS particles; b) NGA particles.

The NGA, BFS and AC 60-70 were characterized following [7] specifications. The results are presented in Tables 1 and 2. Values of the NGA and AC 60-70 meet the requirements of [7] 
specifications for manufacturing type HMA-19 asphalt mixes, but those of the BFS do not because of their low resistance to abrasion on Los Angeles machine and Micro-Deval tests. Nevertheless, the BFS has good resistance to crushing under a monotonic load, based on the results of the $10 \%$ of fines test. Most BFS particles have rounded angular and fractured faces with only a very small portion of elongated and flattened particles, and fine particles have no clay content. Chemical and mineralogical composition determined by X-ray crystallography, X-ray fluorescence tests, and scanning electron microscope observations of the NGA and BFS used can be consulted in [3]. According to them, the predominant mineral in both samples is quartz (silica - $\mathrm{SiO}_{2}$ ). The main difference between them is that the BFS has more $\mathrm{CaO}$ while the NGA contains several clay minerals. The BFS sample is mainly (92.76\%) composed of silica, calcium oxide $(\mathrm{CaO})$, and aluminum oxide $\left(\mathrm{Al}_{2} \mathrm{O}_{3}\right)$ while the NGA sample is mainly (86.86\%) composed of silica and $\mathrm{Al}_{2} \mathrm{O}_{3}$. In addition, BFS particles have higher porosity than do NGA particles.

Table 1. NGA and BFS test results

\begin{tabular}{|l|c|c|c|c|}
\hline \multicolumn{1}{|c|}{ Test } & Method & Recommended & NGA & BFS \\
\hline Specific gravity/fine aggregate absorption & {$[30]$} & - & $2.64 / 1.7 \%$ & - \\
\hline Specific gravity/coarse aggregate absorption & {$[31]$} & - & $2.52 / 1.62 \%$ & $2.1 / 4.5 \%$ \\
\hline Fractured particles (1 side) & {$[32]$} & $85 \%$ minimum & $89 \%$ & $93 \%$ \\
\hline Flattening index & {$[33]$} & $10 \%$ maximum & $8.9 \%$ & $4.7 \%$ \\
\hline Elongation index & {$[33]$} & $10 \%$ maximum & $7.6 \%$ & $3.0 \%$ \\
\hline Plasticity Index & {$[34]$} & Not plastic & Not plastic & Not plastic \\
\hline $10 \%$ of fines (dry resistance) & {$[35]$} & $100 \mathrm{kN}$ minimum & $133 \mathrm{kN}$ & $111 \mathrm{kN}$ \\
\hline Micro-Deval & {$[36]$} & $20 \%$ maximum & $18.8 \%$ & $33.7 \%$ \\
\hline Abrasion in Los Angeles machine & {$[37]$} & $25 \%$ maximum & $23.7 \%$ & $47.2 \%$ \\
\hline
\end{tabular}

Table 2. AC 60-70 test results

\begin{tabular}{|l|c|c|c|c|}
\hline \multicolumn{1}{|c|}{ Test } & Method & Unit & Recommended value & Result \\
\hline \multicolumn{5}{|c|}{ Tests on the original asphalt } \\
\hline Specific gravity & {$[38]$} & - & - & 1.012 \\
\hline Penetration $\left(25^{\circ} \mathrm{C}, 100 \mathrm{~g}, 5 \mathrm{~s}\right)$ & {$[39]$} & $0.1 \mathrm{~mm}$ & $60-70$ & 62.5 \\
\hline Penetration Index & {$[40]$} & - & $-1.2 /+0.6$ & -0.94 \\
\hline Viscosity $\left(60^{\circ} \mathrm{C}\right)$ & {$[41]$} & Poises & 1500 minimum & 1770 \\
\hline Softening point & {$[42]$} & ${ }^{\circ} \mathrm{C}$ & $48-54$ & 49 \\
\hline Ductility $\left(25^{\circ} \mathrm{C}, 5 \mathrm{~cm} / \mathrm{min}\right)$ & {$[43]$} & $\mathrm{cm}$ & 100 minimum & $>105$ \\
\hline
\end{tabular}




\begin{tabular}{|l|c|c|c|c|}
\hline Flash point & {$[44]$} & ${ }^{\circ} \mathrm{C}$ & 230 minimum & 289 \\
\hline \multicolumn{3}{|c|}{ Tests on residue after RTFOT (Rolling Thin Film Oven Test) } \\
\hline Mass loss & {$[45]$} & $\%$ & 0.8 maximum & 0.63 \\
\hline $\begin{array}{l}\text { Penetration }\left(25^{\circ} \mathrm{C}, 100 \mathrm{~g}, 5 \mathrm{~s}\right), \text { as } \\
\text { a percentage of the original } \\
\text { penetration }\end{array}$ & {$[39]$} & $\%$ & 50 minimum & 77 \\
\hline
\end{tabular}

\subsection{CONTROL HMA DESIGN}

The control, HMA-19 without BFS, was designed on the basis of Marshall Test measurements made employing cylindrical Marshall-type specimens [46]. Samples weighing 1,200 g were compacted at 75 blows per face. The grain size distribution of the HMA-19 is presented in Table 3 . This type of HMA, can be used as asphalt surface or base layer. In order to obtain the optimum asphalt content (OAC), four different hot asphalt mixtures were manufactured using proportions of asphalt in the mix as measured by mass of $4.5 \%, 5.0 \%, 5.5 \%$, and $6.0 \%$. Three samples of each were tested. The mixing temperature was $150{ }^{\circ} \mathrm{C}$ (asphalt viscosity of $170 \mathrm{cP}$ ), and the compaction temperature was $140{ }^{\circ} \mathrm{C}$ (asphalt viscosity of $280 \mathrm{cP}$ ). Bulk specific gravities and volumetric compositions of the compacted HMAs were obtained on the basis of [47]. In addition to OAC, Marshall Tests results included volumetric composition (percentage volume of air voids, voids in mineral aggregate-VMA, and voids filled with asphalt-VFA) and the resistance under monotonic loading of the HMA (stability-S, flow-F, and S/F ratio).

Table 3. Particle size distribution of HMA-19

\begin{tabular}{|c|c|c|c|}
\hline Sieve & Sieve (mm) & Percent passing (\%) & Percent retained (\%) \\
\hline $3 / 4 "$ & 19.00 & 100.0 & 0.0 \\
\hline $1 / 2 "$ & 12.50 & 87.5 & 12.5 \\
\hline $3 / 8^{\prime \prime}$ & 9.50 & 79.0 & 8.5 \\
\hline 4 & 4.75 & 57.0 & 22.0 \\
\hline 10 & 2.00 & 37.0 & 20.0 \\
\hline 40 & 0.43 & 19.5 & 17.5 \\
\hline 80 & 0.18 & 12.5 & 7.0 \\
\hline 200 & 0.075 & 6.0 & 6.5 \\
\hline Bottom & - & 0.0 & 6.0 \\
\hline
\end{tabular}




\subsection{BFS TREATMENT WITH PC}

Initially, 1,000 $\mathrm{g}$ of PC were mixed with $500 \mathrm{~g}$ of water in a laboratory tray. These quantities were chosen by trial and error taking into account that the cement paste easily entered the pores of the BFS. Then, BFS particles were introduced into the cement paste and kept there for three days (Fig. 2a). The temperature of the cement paste was maintained at $20^{\circ} \mathrm{C}$. During this time, the BFS particles were stirred to prevent the PC from settling onto the bottom of the tray so that it could more easily enter into the spaces among the particles. At the end of the three day period, excess cement paste was removed. Finally, BFS particles partially covered with PC were cured for one week. This material was named BFS-C (Fig. 2b). BFS-C particles were characterized in a manner similar to that used for NGA and BFS (see Table 4). BFS-C exhibited less adsorption, but higher specific gravity and abrasion resistance, than did untreated BFS.

a)

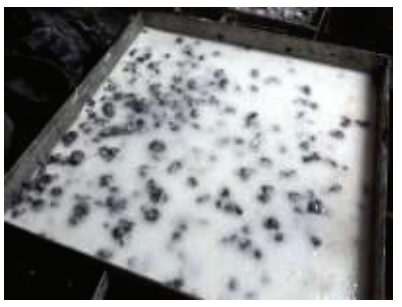

b)

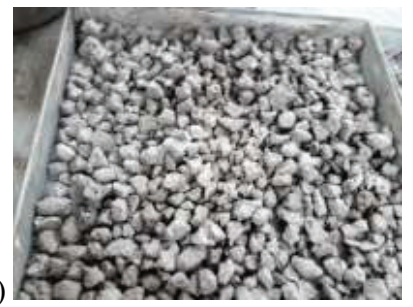

Fig. 2. a) BFS introduced into PC paste; b) BFS-C.

Table 4. BFS-C test results

\begin{tabular}{|l|c|c|}
\hline \multicolumn{1}{|c|}{ Test } & Method & BFS-C \\
\hline Specific gravity/coarse aggregate absorption & AASHTO (1991) & $2.3 / 2.8 \%$ \\
\hline Micro-Deval & AASHTO (2012) & $25.5 \%$ \\
\hline Abrasion in Los Angeles machine & AASHTO (1991a) & $33.1 \%$ \\
\hline
\end{tabular}

\subsection{Marshall AND Indirect Tensile STREngth (ITS) TeStS}

Marshall Tests were performed on samples made with the optimum asphalt content but with six different mixtures: three containing NGA and BFS rather than just NGA, and three others containing NGA and BFS-C. The first mixture replaced $12.5 \%$ of the mass of NGA with BFS (material retained on $1 / 2$ inch sieve), the second replaced $21 \%$ of the NGA with BFS (material 
retained on $3 / 8$ inch sieve), and the third replaced $43 \%$ (material retained on sieve No. 4) of the NGA with BFS. The three new mixtures were named BFS-12.5, BFS-21 and BFS-43, respectively. The three other mixtures used the same proportions, but of BFS-C instead of untreated BFS, and were named BFS-C-12.5, BFS-C-21 and BFS-C-43, respectively. Three samples of each mixture were measured with the Marshall test. The mixing and compaction temperatures were the same as those used for the control HMA $\left(150^{\circ} \mathrm{C}\right.$ and $140{ }^{\circ} \mathrm{C}$, respectively).

Initially, six Marshall-type samples of control HMA were manufactured for ITS tests. In most respects, fabrication followed the [48] standard and used OAC with NGA as the only aggregate without BFS or BFS-C. Unlike the [48] standard process, the samples were not manufactured to reach a void content of $7 \pm 1 \%$ because researchers wanted to evaluate the resistance of the samples without changing the air void content achieved at OAC. Three samples were tested under dry conditions (ITS-D) and three others were tested under wet conditions (ITS-W). Resistance to moisture damage was evaluated through the tensile strength ratio (TSR $=$ ITS-W/ITS-D) expressed as a percentage. Samples to be tested under wet conditions were placed in a saturation vacuum with a pressure of approximately $6.7 \mathrm{kPa}$ for 5 minutes. Then the specimens were submerged for another $10 \mathrm{~min}$. in a water bath. Thereafter, the samples were submerged in a water bath at $60{ }^{\circ} \mathrm{C}$ for $24 \mathrm{~h}$. Prior to the indirect tensile tests, the samples were submerged in water at $25^{\circ} \mathrm{C}$ for $2 \mathrm{~h}$.

In addition, six other samples, three tested under dry conditions and three tested under wet conditions, were manufactured and tested using the OAC but replacing the NGA with BFS-12.5, BFS-21, BFS-43, BFS-C-12.5, BFS-C-21 and BFS-C-43. These samples were tested following the same procedure described above for the control HMA.

\subsection{RESILIENT MODULUS TESTS}

Resilient modulus tests [49] were conducted on the control HMA-19 (without BFS) as well as on most mixtures with BFS and BFS-C at $20^{\circ} \mathrm{C}$ and $30^{\circ} \mathrm{C}$ and at three loading frequencies, 2.5, 5.0 and $10.0 \mathrm{~Hz}$ (haversine waveform with 125, 63 and $31 \mathrm{~ms}$ of the time of load application, and 275, 137 and $69 \mathrm{~ms}$ to the rest time, respectively). BFS-12.5 and BFS-12.5-C were excluded because researchers wanted to use significant amounts of slag, and BFS-43 was excluded because of its Marshall and ITS test results. Tests were executed using a Universal Testing Machine (UTM-30). Each resilient modulus test was carried out on six samples, three for each temperature. For each test temperature, the Marhall specimens (101.6 $\mathrm{mm}$ in diameter and $63.5 \mathrm{~mm}$ in height) were placed in 
the climatic chamber for $4 \mathrm{~h}$ before testing. The amplitude of the load was controlled in order to keep the deformation level below 50 microstrain units in accordance with [49].

\subsection{Cantabro Test}

The Cantabro test is a useful tool for providing durability indices, including for non-load-associated cracking, raveling and weathering, of dense graded asphalt mixes [50]. Three Marshall-type samples of each HMA-19 mixture were tested following [51]. Since the resilient modulus test is not destructive, the same samples employed in resilient modulus tests were used for Cantabro testing. Each sample was tested at $20^{\circ} \mathrm{C}$ in a Los Angeles abrasion machine for 500 revolutions without the charge of steel spheres. The sample mass loss was expressed as percentages of the original sample mass and of the final mass measured after the test.

\section{RESULTS}

\subsection{CONTROL HMA DESIGN}

Marshall Test results for control HMA-19 are shown in Table 5. The OAC was 5.3\%, based on the requirements established by [7] for HMA-19 mixtures.

Table 5. Marshall Test results for control HMA-19.

\begin{tabular}{|c|c|c|c|c|c|c|}
\hline $\mathrm{AC}(\%)$ & $\mathrm{S}(\mathrm{kN})$ & $\mathrm{F}(\mathrm{mm})$ & $\mathrm{S} / \mathrm{F}(\mathrm{kN} / \mathrm{mm})$ & Air voids (\%) & VMA (\%) & VFA (\%) \\
\hline 4.5 & 11.3 & 4.0 & 2.8 & 6.8 & 16.7 & 59.6 \\
\hline 5.0 & 12.1 & 3.8 & 3.2 & 5.1 & 16.3 & 68.6 \\
\hline 5.5 & 12.4 & 3.7 & 3.3 & 3.5 & 16.0 & 77.9 \\
\hline 6.0 & 11.3 & 4.2 & 2.7 & 2.4 & 16.0 & 85.3 \\
\hline
\end{tabular}

\subsection{Marshall AND Indirect Tensile StREngth (ITS) TESTS}

Fig. 3 shows Marshall test results, and Table 6 shows ITS Tests results. The S/F ratio, ITS-D and ITS-W all decreased as the BFS content increased. This was mainly due to increasing air void content. In addition, mixtures containing BFS require more asphalt to cover all of the particles. This 
occurs in part because there are a larger number of particles in the BFS mixtures than the number of NGA particles in the control mixture, but also because BFS's specific gravity is lower than that of NGA and this results in poorer adhesion and lessened ITS resistance. On the other hand, in the pretreated BFS-C, the PC reduces the air void content and adsorption resulting in a notable increase in the S/F ratio, ITS and TSR (Despite this, the BFS-C's air void ratios are still higher than that of the control HMA.). These increments could be due to the PC film that partially covers the surface and to the porosity of the BFS particles. The S/F ratio increased, with respect to control HMA by $35 \%$ $(1.2 \mathrm{kN} / \mathrm{mm})$ when BFS-C-12.5 was used, by $21 \%(0.71 \mathrm{kN} / \mathrm{mm})$ when BFS-C-21 was used, and by $9.5 \%(0.33 \mathrm{kN} / \mathrm{mm})$ when BFS-C-43 was used. For ITS-D tests, the increments were $26.5 \%, 20 \%$, and $4.2 \%$ respectively while increments were $34.4 \%, 26.4 \%$ and $8.9 \%$, respectively for ITS-W tests. The S/F ratios of BFS-C were between $30 \%$ and $45 \%$ higher than the S/F ratio of HMA $(0.95$ $\mathrm{kN} / \mathrm{mm}$ to $1.44 \mathrm{kN} / \mathrm{mm}$ ), the ITS-D of BFS-C was between $22 \%$ and $30 \%$ higher, and its ITS-W was between $38 \%$ and $50 \%$ higher.

a)

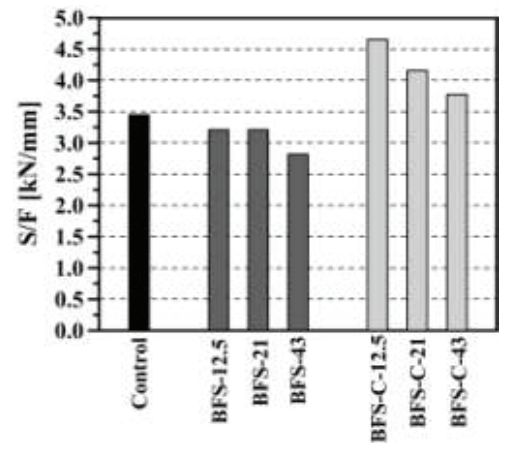

b)

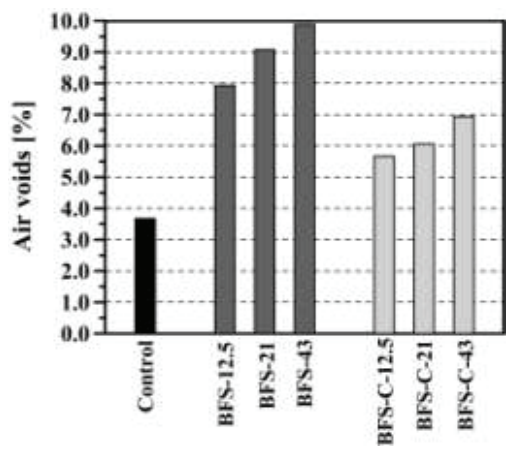

Fig. 3. a) Evolution of S/F ratio; b) Evolution of air void content

Table 6. ITS Test results.

\begin{tabular}{|c|c|c|c|c|}
\hline Mixture & Air Voids (\%) & ITS-D (kPa) & ITS-W (kPa) & TSR (\%) \\
\hline Control & 3.9 & 1093.3 & 933.3 & 85.4 \\
\hline BFS-12.5 & 7.7 & 1061.9 & 837.0 & 78.8 \\
\hline BFS-21 & 8.8 & 1024.9 & 820.3 & 80.0 \\
\hline BFS-43 & 9.7 & 937.9 & 738.3 & 78.7 \\
\hline BFS-C-12.5 & 6.0 & 1383.0 & 1254.7 & 90.7 \\
\hline BFS-C-21 & 6.7 & 1312.3 & 1179.3 & 89.9 \\
\hline BFS-C-43 & 7.3 & 1139.6 & 1016.5 & 89.2 \\
\hline
\end{tabular}




\subsection{RESILIENT MODULUS}

Fig. 4 shows the results of resilient modulus tests. BFS-12.5 and BFS-12.5-C were excluded because researchers wanted to use significant amounts of slag, and BFS-43 was excluded because of the results obtained in the Marshall and ITS tests.

The HMA mixture with BFS-C-21 tends to be more rigid under cyclic loading than the control HMA. The increment in the resilient modulus ranged between $6 \%$ and $26 \%$ at $20^{\circ} \mathrm{C}$ and between $35 \%$ and $72 \%$ at $30^{\circ} \mathrm{C}$. BFS-21 and BFS-43 developed resilient moduli similar to that of the control HMA at $20^{\circ} \mathrm{C}$, but slightly higher than the control at $30^{\circ} \mathrm{C}$.

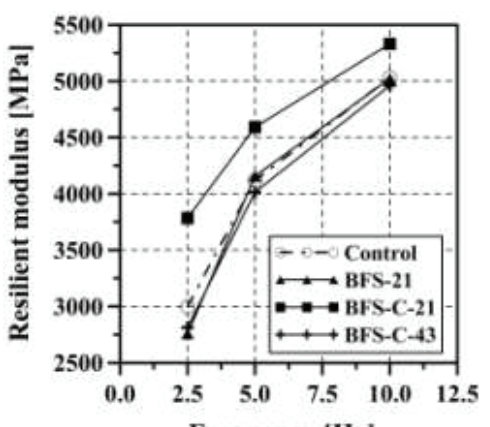

a)
Frequency [Hz]

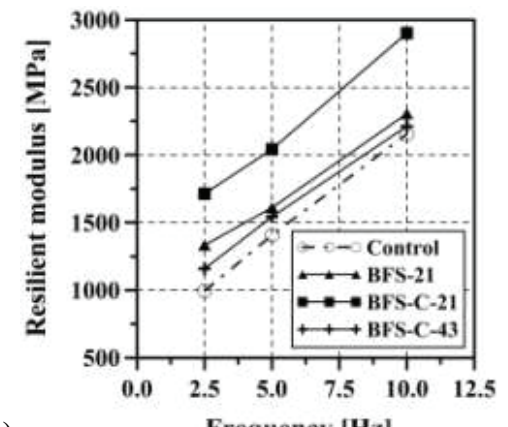

b)

Frequency $[\mathrm{Hz}]$

Fig. 4. Evolution of resilient moduli at a) $20^{\circ} \mathrm{C}$ and b) $30^{\circ} \mathrm{C}$.

\subsection{CAntabro test}

Table 7 shows the results of the Cantabro test. HMA with BFS lost significantly more mass in the Cantabro test than did the control mixture. While BFS-C also lost more mass than the control, the difference was much smaller. This is mainly due to the fact that the BFS-C particles have greater abrasion resistance in the Los Angeles machine than do the untreated BFS particles.

Table 7. Cantabro Test results

\begin{tabular}{|l|c|c|}
\hline \multicolumn{1}{|c|}{ Mixture } & Air Void Content (\%) & Mass loss (\%) - 500 revolutions \\
\hline Control & 4.1 & 10.9 \\
\hline BFS-21 & 8.3 & 32.1 \\
\hline BFS-C-21 & 6.5 & 21.1 \\
\hline
\end{tabular}




\section{CONCLUSIONS}

In this study, the pores of a BFS were partially filled with a PC paste. This treated material was used to replace the coarse natural aggregate fraction of an HMA. Based on the results obtained, the following conclusions specifically for the BFS analysed can be drawn:

- Replacement of the coarse natural aggregate fraction of HMA with BFS increased the air void content and decreased mechanical resistance under monotonic loading ( $\mathrm{S} / \mathrm{F}$ ratio, ITS-D and ITS-W decreased as BFS content increased). Resistance to moisture damage also decreased. However, when BFS-C was used, the S/F ratio, ITS-D and ITS-W all increased indicating increased resistance under monotonic loading and moisture damage.

- Resilient modulus is directly correlated with stiffness under cyclic loading and permanent deformation resistance of HMA mixtures. HMA with BFS has a resilient modulus that is similar to that of control $\mathrm{HMA}$ at a test temperature of $20^{\circ} \mathrm{C}$. At $30^{\circ} \mathrm{C}$, HMA with BFS has a slightly higher resilient modulus. An increase in the stiffness under cyclic loading was obtained when $21 \%$ of the coarse natural aggregate fraction was replaced by BFS-C. When $43 \%$ was replaced by BFS-C, the resilient modulus was similar to that of control HMA.

- In the HMA, BFS generated a significantly larger Cantabro mass loss than that of the control asphalt mixture. BFS-C had better Cantabro abrasion resistance, but the HMA with this material is still less resistant than the control mixture.

- In general terms, treatment of BFS with PC paste was beneficial because the adsorption of BFS particles deceased and their abrasion resistance increased. This treated material could be used to replace the coarse fraction of natural aggregates in order to improve the mechanical properties of HMA mixtures.

\section{REFERENCES}

1. S. Akbarnejad, L. J. M. Houben, A. A. A. Molenaar, "Application of aging methods to evaluate the long-term performance of road bases containing blast furnace slag materials", Road Materials and Pavement Design 15(3): 488-506, 2014. https://doi.org/10.1080/14680629.2014.907196.

2. H. A. Rondón, J. C. Ruge, M. Farias, "Behavior of a hot mix asphalt containing blast furnace slag as aggregate: evaluation by mass and volume substitution”, Journal of Materials in Civil Engineering 31(2), 2019. https://doi.org/10.1061/(ASCE)MT.1943-5533.0002574.

3. H. A. Rondón, J. C. Ruge, D. Patiño, H. Vacca, F. A. Reyes, M. Farias, "Use of blast furnace slag as a substitute for the fine fraction of aggregates in an asphalt mixture", Journal of Materials in Civil Engineering 30(10), 2018. http://dx.doi.org/10.1061/(ASCE)MT.1943-5533.0002409. 
4. A. Jamshidi, K. Kurumisawa, T. Nawa, M. Jize, G. White, "Performance of pavements incorporating industrial byproducts: a state-of-the-art study", Journal of Cleaner Production 164: 367-388, 2017. https://doi: 10.1016/j.jclepro.2017.06.223.

5. Z. Zarei, M. B. Reza, "Application of iron slag at different pavement layers", Journal of Environmental Treatment Techniques 3(3): 158-162, 2015.

6. FHWA (Federal Highway Administration Research and Technology), "Coordinating, developing, and delivering highway transportation innovations: User guidelines for waste and byproduct materials in pavement construction”, Rep. Publication Number: FHWA-RD-97-148. Washington, DC: FHWA, 2008.

7. INVIAS (Instituto Nacional de Vías), "Especificaciones generales de construcción de carreteras [General specifications for road and highways construction]”, Bogotá, Colombia: INVIAS, 2013.

8. K. A. Vaughan, "An investigation of cement coating for aggregates in bituminous material”, Ph. D. thesis, Liverpool John Moores University, 1999. 10.24377/LJMU.t.00005989.

9. D. Lesueur, D. Little, "Effect of hydrated lime on rheology, fracture, and aging of bitumen", Transportation Research Record 1661: 93-105, 1999. https://doi.org/10.3141/1661-14.

10. G. D. Airey, A. C. Collop, S. E. Zoorob, R. C. Elliott, "The influence of aggregate, filler and bitumen on asphalt mixture moisture damage", Construction and Building Materials 22(9): 2015-2024, 2008. https://doi.org/10.1016/j.conbuildmat.2007.07.009.

11. V. Antunes, A. C. Freire, L. Quaresma, R. Micaelo, "Effect of the chemical composition of fillers in the fillerbitumen interaction", Construction and Building Materials 104: 85-91, 2016. https://doi.org/10.1016/j.conbuildmat.2015.12.042.

12. D. Movilla-Quesada, A. C. Raposeiras, D. Castro-Fresno, D. Peña-Mansilla, "Experimental study on stiffness development of asphalt mixture containing cement and $\mathrm{Ca}(\mathrm{OH})_{2}$ as contribution filler", Materials \& Design 74: 157-63, 2015. https://doi.org/10.1016/j.matdes.2015.02.026.

13. S. Du, "Performance characteristic of cold recycled mixture with asphalt emulsion and chemical additives", Advances in Materials Science and Engineering 2015: 1-10, 2015. http://dx.doi.org/10.1155/2015/271596.

14. D. Lesueur, A. Teixeira, M. M. Lázaro, D. Andaluz, A. Ruiz, "A simple test method in order to assess the effect of mineral fillers on bitumen ageing", Construction and Building Materials 117: 182-189, 2016. http://dx.doi.org/10.1016/j.conbuildmat.2016.05.003.

15. I. Ishai, S. Nesichi, "Laboratory evaluation of moisture damage to bituminous paving mixtures by long-term hot immersion", Transportation Research Record 1171: 12-17, 1988. http://worldcat.org/isbn/0309047102.

16. A. Gundla, J. Medina, P. Gudipudi, R. Stevens, R. Salim, W. Zeiada, B. Underwood, "Investigation of aging in hydrated lime and portland cement modified asphalt concrete at multiple length scales", Journal of Materials in Civil Engineering 28(5), 2016. https://doi.org/10.1061/(ASCE)MT.1943-5533.0001501.

17. G. G. Al-Khateeb, N. M. Al-Akhras, "Properties of Portland cement-modified asphalt binder using Superpave tests", Construction and Building Materials 25(2): 926-932, 2011. https://doi.org/10.1016/j.conbuildmat.2010.06.091.

18. T. Saadoon, B. Gómez-Meijide, A. Garcia, "Prediction of water evaporation and stability of cold asphalt mixtures containing different types of cement", Construction and Building Materials 186: 751-761, 2018. https://doi.org/10.1016/j.conbuildmat.2018.07.218.

19. Y. Niazi, M. Jalili, "Effect of Portland cement and lime additives on properties of cold in-place recycled mixtures with asphalt emulsion", Construction and Building Materials 23: 1338-43, 2009. https://doi.org/10.1016/j.conbuildmat.2008.07.020

20. S. Likitlersuang, T. Chompoorat, "Laboratory investigation of the performances of cement and fly ash modified asphalt concrete mixtures", Internation Journal of Pavement Research and Technology 9: 337-344, 2016. http://dx.doi.org/10.1016/j.ijprt.2016.08.002.

21. S. Oruc, F. Celik, M. V. Akpinar, "Effect of cement on emulsified asphalt mixtures", Journal of Materials Engineering and Performance 16(5): 578-583, 2007. https://doi.org/10.1007/s11665-007-9095-2.

22. L. Fang, Q. Yuan, D. Deng, Y. Pan, Y. Wang, "Effect of mix parameters on the dynamic mechanical properties of cement asphalt mortar", Journal of Materials in Civil Engineering 29(8), 2017. https://doi.org/10.1061/(ASCE)MT.1943-5533.0001913.

23. J. Ouyang, J. Zhao, Y. Tan, "Modeling mechanical properties of cement asphalt emulsion mortar with different asphalt to cement ratios and temperatures", Journal of Materials in Civil Engineering 30(10), 2018. https://doi.org/10.1061/(ASCE)MT.1943-5533.0002480.

24. X. Kong, Y. Liu, Y. Zhang, Z. Zhang, P. Yan, Y. Bai, "Influences of temperature on mechanical properties of cement asphalt mortars", Materials and Structures 47(1-2): 285-292, 2014. https://doi.org/10.1617/s11527013-0060-2.

25. N. Pouliot, J. Marchand, M. Pigeon, "Hydration mechanisms, microstructure, and mechanical properties of mortars prepared with mixed binder cement slurry-asphaltemulsion", Journal of Materials in Civil Engineering 15(1), 2003. https://doi.org/10.1061/(ASCE)0899-1561(2003)15:1(54). 
26. G. D. Airey, A. C. Collop, N. H. Thom, "Mechanical performance of asphalt mixtures incorporating slag and glass secondary aggregates", In Proc., 8th Conf. Asphalt Pavements for Southern Africa (CAPSA'04). Pretoria, South Africa: CSIR Transportek, Asphalt Academy, 2004.

27. L. Ali, A. Fiaz, "Use of fly ash along with blast furnace slag as partial replacement of fine aggregate and mineral filler in asphalt mix, at high temperature", In GeoHunan International Conference 2009, Changsha, Hunan, China: American Society of Civil Engineering, 2009. https://doi.org/10.1061/41045(352)18.

28. H. A. Rondón, S. Chaves, D. Escobar, "Evaluation of a warm mix asphalt manufactured with blast furnace slag", Modern Applied Science 12(12): 28-40, 2018. doi:10.5539/mas.v12n12p28.

29. S. Du, "Mechanical properties and reaction characteristics of asphalt emulsion mixture with activated ground granulated blast-furnace slag", Construction and Building Materials 187: 439-447, 2018. https://doi.org/10.1016/j.conbuildmat.2018.07.233.

30. AASHTO. 2000. Standard method of test for specific gravity and absorption of fine aggregate. AASHTO T84. Washington, DC: AASHTO.

31. AASHTO. 1991. Standard method of test for specific gravity and absorption of coarse aggregate. AASHTO T85. Washington, DC: AASHTO.

32. ASTM. 2001. Standard test method for determining the percentage of fractured particles in coarse aggregate. ASTM D5821. West Conshohocken, PA: ASTM.

33. NLT (Norma Laboratorio de Transporte). 1991. Standard method for the determination of the flakiness index of the aggregate. NLT 354. Madrid, Spain: Centro de Estudios y Experimentación de Obras Públicas.

34. ASTM. 2000. Standard test methods for liquid limit, plastic limit, and plasticity index of soils. ASTM D4318. West Conshohocken, PA: ASTM.

35. DNER (Departamento Nacional de Estradas de Rodagem). 1998. Avaliação da resistência mecânica pelo método dos $10 \%$ de finos [Evaluation of mechanical resistance to coarse aggregate using $10 \%$ method]. DNER-ME 096. Rio de Janeiro, Brazil: Departamento Nacional de Infraestrutura de Transporte.

36. AASHTO. 2012. Standard method of test for resistance of coarse aggregate to degradation by abrasion in the Micro-Deval apparatus. AASHTO T327. Washington, DC: AASHTO.

37. AASHTO. 1991a. Standard method of test for resistance to degradation of small-size coarse aggregate by abrasion and impact in the Los Angeles machine. AASHTO T96. Washington, DC: AASHTO

38. AASHTO. 2004. Standard method of test for specific gravity of semi-solid asphalt materials. AASHTO T228. Washington, DC: AASHTO.

39. ASTM. 2013. Standard test method for penetration of bituminous materials. ASTM D5/D5M. West Conshohocken, PA: ASTM.

40. NLT (Norma Laboratorio de Transporte). 1988. Método para determinar la variación de la consistencia del betún asfáltico con los cambios de temperatura (susceptibilidad) [Method to determine the variation in the consistency of asphalt bitumen with temperature changes (susceptibility)]. NLT 181. Madrid, Spain: Normas NLT.

41. ASTM. 2015. Standard test method for viscosity determination of asphalt at elevated temperatures using a Rotational Viscometer. ASTM D4402/D4402M. West Conshohocken, PA: ASTM.

42. ASTM. 2006. Standard test method for softening point of bitumen (Ring-and-Ball apparatus). ASTM D36. West Conshohocken, PA: ASTM.

43. ASTM. 1999. Standard test method for ductility of bituminous materials. ASTM D113. West Conshohocken, PA: ASTM.

44. ASTM. 2001a. Standard test method for flash and fire points by Cleveland Open Cup. ASTM D92. West Conshohocken, PA: ASTM.

45. ASTM. 2012. Standard test method for effect of heat and air on a moving film of asphalt (Rolling Thin-Film Oven Test). ASTM D2872-12e1. West Conshohocken, PA: ASTM.

46. AASHTO. 2015. Standard method of test for resistance to plastic flow of bituminous mixtures using Marshall apparatus. AASHTO T245. Washington, DC: AASHTO.

47. AASHTO. 2014. Standard method of test for percent air voids in compacted dense and open asphalt mixtures. AASHTO T269. Washington, DC: AASHTO.

48. AASHTO. 2014a. Standard method of test for resistance of compacted asphalt mixtures to moisture-induced damage. AASHTO T283. Washington, DC: AASHTO.

49. BSI (British Standards Institution). 2005. Bituminous mixtures test methods for hot mix asphalt. Part 26: Stiffness. BS EN 12697-26. London: BSI.

50. B. C. Cox, B. T. Smith, I. L. Howard, R. S. James, "State of knowledge for Cantabro testing of dense graded asphalt", Journal of Materials in Civil Engineering 29(10): 04017174, 2017. doi.org/10.1061/(ASCE)MT.1943-5533.0002020.

51. NLT (Norma Laboratorio de Transporte). 1986. Caracterización de las mezclas bituminosas abiertas por medio del ensayo Cántabro de pérdida por desgaste [Characterization of open or porous aspahlt mixtures using abrasion Cantabro test]. NLT 352. Madrid, Spain: Normas NLT. 


\section{LIST OF FIGURES AND TABLES:}

Fig. 1. a) BFS particles; b) NGA particles

Fig. 2. a) BFS introduced into PC paste; b) BFS-C

Fig. 3. a) Evolution of S/F ratio; b) Evolution of air voids - Va content

Fig. 4. Evolution of resilient modulus. a) $20^{\circ} \mathrm{C}$ and b) $30^{\circ} \mathrm{C}$

Table 1. NGA and BFS test results

Table 2. AC 60-70 test results

Table 3. Particle size distribution of HMA-19

Table 4. BFS-C test results

Table 5. Marshall Test results for control HMA-19

Table 6. ITS Test results

Table 7. Cantabro Test results

Received 25.04.2019

Revised 30.06.2019 